\title{
Rábai Dávid \\ A SáNDOR Károly LabDarúgó AKadÉmia \\ ÉS A DebreCENI LabDARÚgó AKadÉmIA MegaLAKULÁSÁNAK ÖSSZEHASONLító \\ VIZSGÁLATA
}

DOI 10.35402/kek.2019.2.4

\begin{abstract}
Absztrakt
Tanulmányunkban arra vállalkoztunk, hogy felderítsük és összehasonlítsuk a Sándor Károly Labdarúgó Akadémia és a Debreceni Labdarúgó Akadémia kialakulási történetét, elsősorban a témában született szakirodalom, illetve az említett akadémiák szakmai igazgatóival felvett interjúk elemzésének segítségével. Kutatásunkban feltártuk és elemeztük az agárdi székhelyủ Sándor Károly Labdarúgó Akadémia megalapítási előzményeit, majd kutatásunk második részében a vidéken székhelyező Debreceni Labdarúgó Akadémia kialakulási körülményeit vettük górcső alá és hasonlítottuk össze a Sándor Károly Labdarúgó Akadémiáéval. Kíváncsiak voltunk arra, hogy egy vidéki akadémia megalakulását vizsgálva milyen azonosságok és különbségek jelentkeznek egy fóvárosi akadémiával összevetve az eredményeket. Kutatásunkhoz a félig strukturált interjúk felvételének módszerét alkalmaztuk. Mindkét labdarúgó akadémia esetében személyesen látogattunk el a helyszínre, tapasztalatot gyűjtve ezzel az ottani miliőről, az adott akadémia környezetéről. Összesen három interjút vettünk fel a kutatásunk kapcsán, mindhárom esetben az interjúalanyaink a helyszíneken válaszoltak a kérdéseinkre.
\end{abstract}

A kutatás eredményeképpen elmondható, hogy a Sándor Károly Labdarúgó Akadémia merőben más megalakulási előzménnyel rendelkezik, mint a vidéki székhelyủ Debreceni Labdarúgó Akadémia. Az agárdi akadémia (amely az első honi labdarúgó akadémiaként jött létre 2001-ben) egy magánkezdeményezés alapján alakult meg, amely konkrétan Várszegi Gábor ötletéhez és annak megvalósításához köthető. Éppen ebből kifolyólag a kutatás során szintén kiderült, hogy a dolgozatban az általunk is tárgyalt, fóként a 90'-es évekre tehető labdarúgó utánpótlás-fejlesztésének előmozdítása érdekében született programoknak és kezdeményezéseknek (pl.: Olasz Focisuli, Góliát McDonald's FC, stb.) érdemben nem volt közük hazánk első labdarúgó akadémiáánanak megalakulásában. A Debreceni Labdarúgó Akadémia kialakulási körülményeinek feltárása során bekapcsolódtunk a LearnInnov kutatásba (Kozma és mtsai). A kutatási eredményeink alapján ebben az esetben nem egy magánszemély által kezdeményezett és megvalósított elképzelésről beszélhetünk, hanem a helyi erők hathatós összefogásáról, amely az akadémiai fenntartók által valósulhatott meg.

\section{Abstract}

In our present paper we undertook that we explore and compare the history of Sándor Károly Football Academy and Debrecen Football Academy development story literature was born in the topic primarily, with the help of the analysis of interviews put on concerned with the Technical Directors of the mentioned academies. Then we explored and analyzed the founding history of the Károly Sándor Football Academy based in Agárd, in the second part of our research and then we looked at the formation conditions of the Debrecen Football Academy and compared it with Sándor Károly Football Academy. We were curious about what a rural academy is like examining his forming identities and differences come forward comparing the results with a metropolitan academy. We used the method of recording semi-structured interviews for our research. For both football academies, we personally visited the venue, gathering experience from the milieu there from the surrounding academy. We intervieweed three interviews and in all three of our cases, our interviewees answered the questions on the spot.

As a result of the research can be related, that entirely other forming antecedents are at Sándor Károly Football Academy disposal, than Debrecen Football Academy with a rural seat. The Sándor Károly Football Academy (which was established as the first football academy in 2001) was formed on the basis of a private initiative that can be specifically linked to Gábor Várszegi's idea and its implementation (Rábai 2018a). The research has also re- 
vealed that in the paper the merits of the programs and initiatives especially for the 90's (eg. Olasz Focisuli, Góliát McDonald's FC, etc.) had nothing to do with the formation of our first football academy. When exploring the evolutionary conditions of the Debrecen Football Academy, we joined the LearnInnov's research (Kozma et al.). We may not talk about a realized idea initiated by a private person in this case based on our research results, but from the efficacious champing of the local strengths, which may have come true by way of the academic maintainers.

\section{Bevezetés}

A magyar labdarúgás rendkívül sok kritikát kapott az elmúlt évek során. Mindezek a vélemények abból fakadnak elsősorban, hogy az egykoron még világszínvonalon tündöklő magyar futball utolsó fél évszázadát tekintve leginkább a tartós, egyre erőteljesebb visszaesés volt a jellemző (Szegedi 2003). Ezt a visszaesést a szakemberek egységes álláspontja szerint éppen az utánpótlás-fejlesztéssel lehetne lassítani, amely segíthet a hanyatlást megfékezni, illetve a nemzetközi szintekhez felzárkózni (Vincze 2008). Hazánkban a labdarúgás helyzetének javítása érdekében több pozitív töltetű folyamat indult be az utóbbi években, a legtöbbjük fókuszában az utánpótlás-nevelés helyzetének előmozdítását megcélozva. Mindazonáltal az egyes objektív mércékkel mérhető mutatók és a különböző klub vagy nemzeti rangsorok - mint például a magyar labdarúgó válogatott sorozatos elmaradása a rangos világtornáktól vagy éppen a honi klubcsapataink javarészt eredménytelen szereplése a nemzetközi futballban - mind azt mutatják, hogy korántsem talált még magára nemzetünk futballja (Orosz 2009). Hegedűs (2001) szerint az utóbbi években nagy fejlődésen ment keresztül a gyermeklabdarúgás és az utánpótlás-nevelés, hiszen ezrek kezdtek el futballozni hazánkban. Ugyanakkor ezzel párhuzamban a felnőtt labdarúgásunk közel sincs az európai elithez (Hegedűs 2001). Csáki és mtsai (2013) szerint a problémák alapjául szolgál továbbá az is, hogy az utánpótlás-nevelés kérdésköre még nem teljesen megoldott hazánk labdarúgásában, illetve ez még további hiányosságként mutatkozik a sporttudományos élet szféráin belül is (Csáki és mtsai 2013).

A labdarúgó akadémiák folyamatos létrejötte és bázisaik egyre nagyobb szintủ kiszélesedése akár válasz is lehetne erre az útkeresésre. Az ilyen jelle- gủ labdarúgó utánpótlás-központok nem titkoltan azért jönnek létre 2001 óta folyamatosan, hogy a legtehetségesebb labdarúgó-palántákat kisgyermekkortól kezdve a professzionális futballra készítsék fel, nem sajnálva erre a hatalmas infrastrukturális beruházásokat és fejlesztéseket, illetve az ezzel járó pénzügyi befektetéseket. Nem vitás azonban az sem, hogy a labdarúgó akadémiákkal kapcsolatban a hazai közvélemény erősen megosztottnak tekinthető. Ez a megosztottság leginkább annak köszönhető, hogy mind a sportszakmabeliek, mind pedig a laikusok erősen hiányolják azokat a számottevő szakmai sikereket, eredményeket, amelyeket a magyar utánpótlás-labdarúgásnak kellene folyamatosan produkálnia ilyen szintű háttérműködés mellett. Ennek az elvárt eredményességnek lényeges elemeivé váltak a közel 17 éves múlttal rendelkező, a magyar labdarúgás utánpótlás-fejlesztésének érdekében létrehozott labdarúgó akadémiák is. A közvélemény szemében azonban további kérdéseket vetnek fel az ezekkel az intézményekkel szorosan kapcsolatba hozható, nagy volumenü infrastrukturális fejlesztések és a komoly anyagi források, melyek köz- és magánforrásokból egyaránt jelen vannak az egyes akadémiák működésében. Mindezek mellett szintén nem elhanyagolható tényező, hogy a labdarúgó akadémiák homályos jogszabályi környezetben és működési szabályozottságban mozognak a mai napig (Fenyő - Rábai 2016).

A legelső honi labdarúgó akadémiát, a Sándor Károly Labdarúgó Akadémiát 2001-ben alapították meg Agárdon, ez az utánpótlásbázis számít annak az irányadó prototípusnak, amely után a következő években - leginkább a 2000-es évek végén - sorra létesültek a labdarúgó akadémiák hazánkban. Mi sem bizonyítja ezt jobban, hogy hat évvel később további négy élvonalbeli klub döntött úgy, hogy saját akadémiát alapít a klubjának égiszén belül, az első korosztályok pedig 2010-ben végeztek. Az utóbbi években tehát tendenciaszerü, hogy egyegy már évek óta létező utánpótlás-nevelő központ válik akadémiává, amennyiben megfelel az MLSZ által bevezetett, speciálisan a labdarúgó akadémiákra vonatkozó kritériumrendszernek mint például a tanulási, lakhatási, szervezeti és az intézményi feltételek (Fenyő - Rábai 2016).

A honi labdarúgó akadémiai rendszer is rendelkezik kialakulási történettel, viszont hazai viszonylatban ezt korábban még alig vizsgálták tudományos berkekben. Ezért is merült fel érdekes kérdésként a jelen kutatásunk során, hogy milyen megalakulási történettel rendelkeznek ezek az után- 
pótlás-fejlesztésre szakosodott intézmények, van-e esetleg lényeges különbség egy-egy labdarúgó akadémia létrejötte között. Jelen dolgozatunk legfőbb célkitűzése ezek fényében az, hogy összehasonlítsa két labdarúgó akadémia, a Sándor Károly Labdarúgó Akadémia és a Debreceni Labdarúgó Akadémia kialakulási történetét a szakirodalom és a témában felvett interjúk elemzésének segítségével. Azért esett a választás e két akadémia kialakulás-történetének feltárására és összehasonlítására, mert a Sándor Akadémia fővárosi akadémiaként van jelen a magyar akadémiai rendszerben, illetve ez az intézmény hazánk első ilyen jellegű utánpótlás-bázisa, így mintaadó szerepkörrel bír. A Debreceni Akadémia esetében egyrészről sikeres vidéki, másrészről az akadémia-alapítás második hullámához tartozó akadémiáról beszélhetünk, így feltételezhetően markáns különbségeket tudunk felfedezni közöttük a kialakulási körülményeket elemzési fókuszba állítva. Jelen kutatásunk egy másik részében a két akadémia gyakorlatára is kiterjedt vizsgálatunk, azonban mostani tanulmányunkban erre nem teszünk kitekintést a terjedelmi korlátokat is figyelembe véve, így azt egy másik írásunkban kívánjuk boncolgatni a jövőben.

\section{A jelen kutatás módszere, vizsgálati körülményei, kérdései}

Kutatásunk fő módszereként a félig strukturált interjúk felvételét alkalmaztuk. Összesen három interjút vettünk fel a téma kapcsán - az interjúk felvételi körülményeihez tartozó információ, hogy Agárdon, a Sándor Károly Labdarúgó Akadémia, illetve Debrecenben, a Debreceni Labdarúgó Akadémia székhelyein készültek. Az agárdi akadémia vizsgálata során Budapestről Agárdra az egyik interjúalany szállított el bennünket autóval. A beszélgetések a mi megkeresésünk által jöttek létre, az alanyok pedig beleegyeztek a hangfelvételek rögzítésébe, így az elmondottak kiértékelését ez is nagyban megkönynyítette. A jelen összehasonlításon alapuló kutatás közvetlen előzményeként szolgál még, hogy bekapcsolódhattunk a LearnInnov (Kozma és mtsai) kutatás keretein belül zajló, nemrégiben elindult kutatási folyamatba, ahol a közösségi, helyi erők esetleges szerepvállalását vizsgáltuk és vizsgáljuk az egyes települések mellett a labdarúgó akadémiák között is. Ezt alapul véve elemeztük a Debreceni Labdarúgó Akadémia kialakulási körülményeit és állítottuk szembe egy vélhetően egészen más meg- alakulási történettel rendelkező labdarúgó akadémiáéval, a Sándor Akadémiával. A vizsgálatot megelőzően a kutatási kérdésünk az volt, hogy van-e lényeges különbség és ha igen, akkor milyen jellegzetes differencia jelentkezik a Sándor Akadémia és Debreceni Akadémia kialakulási története között.

\section{Eredmények}

\subsection{Az interjú alanyainak bemutatása}

Az agárdi Sándor Károly Labdarúgó Akadémián két interjú felvételére került sor az ott található akadémia és egyúttal a magyar labdarúgó akadémiai rendszer kialakulási körülményeinek feltárása érdekében. Az interjúalanyok közül az egyik alanyunk sok éven keresztül volt az MTK Budapest felnőtt csapatának vezetőedzője, manapság pedig szakmai igazgatóként tevékenykedik a klubnál. Közel 800szor ült vezetőedzőként több csapatnál is NB I-es kispadon, így ezzel csúcstartó a magyar edzők mezőnyében. Érdemes még megjegyezni róla, hogy a magyar labdarúgó válogatott szövetségi kapitánya is volt a $80^{\prime}$-as évek végén néhány mérkőzés erejéig. A másik interjúalany korábban szintén NB I-es edzőként tevékenykedett, 2005-2017 között az agárdi labdarúgó akadémia szakmai igazgatója volt, jelenleg az ETO FC Győr utánpótlás szakmai igazgatójaként tevékenykedik. A Debreceni Labdarúgó Akadémia megalakulása kapcsán egy interjút vettünk fel az akadémia jelenlegi szakmai igazgatójával. Interjúalanyunk már több ízben is irányította a Debreceni VSC felnőtt együttesét, jelenleg is ő az NB I-es egyesület vezetőedzője. Irányításával összesen két bajnoki címet, két Magyar Kupát, két Szuperkupát és egy Ligakupát nyert az együttes. 2009ben vezetésével a Debreceni VSC története során először részt vett a Bajnokok Ligája csoportküzdelmeiben, egy évvel később pedig az Európa-Liga fö tábláján versenyzett a csapat.

\subsection{A Sándor Károly Labdarúgó Akadémia és a Debreceni Labdarúgó Akadémia megalakulási körülményeinek a feltárása, összehasonlitása egymással}

Fejezetünk első felében a magyar labdarúgó akadémiai rendszer úttörőjének számító Sándor Károly Labdarúgó Akadémia létrejöttének körülményeit szeretnénk ismertetni, majd második ré- 
szében - ugyanezen aspektusokat fókuszba állítva - a Debreceni Labdarúgó Akadémia kialakulásának feltárására vállalkoztunk.

Szabados (2008) tanulmányában említést tesz a Sándor Károly Labdarúgó Akadémia létrejöttéről és hozzáteszi, hogy az agárdi intézmény megalapítása volt a példamutató típus a többi élvonalbeli egyesület számára. Szerinte ezután valóságos „akadémialáz" indult be hazánkban, pár évvel később ugyanis gombamódra szaporodtak az ilyen jellegü létesítmények a fơvárosban és a vidéken is egyaránt (Szabados 2008). Varga et al (2018) tanulmányában rámutat arra, hogy hazánk első labdarúgó akadémiáját 2001-ben alapították, majd a 2000-es évek végén már több elit labdarúgó klub is létrehozta a saját akadémiai bázisát. Azt is hozzáteszi, hogy noha ezeknek rendkívül hasonlóak a célkitűzéseik (a legtehetségesebb fiatalok összegyüjtése, oktatása és magas szintű képzése), mindazonáltal markáns különbségek fedezhetők fel mind a szervezeti struktúrájukban, mind a müködésükben és mind a képzési feltételeikben is (Varga et al 2018). Ez a megállapítás jól párhuzamba állítható Rábai és Fenyő (2016) és Rábai (2016) kutatásaikban tapasztaltakkal, akik szintén hasonló eredményeket kaptak az akadémiák jogszabályi, szervezeti és fenntartói összehasonlításakor (Fenyő - Rábai 2016; Rábai 2016). A hazai szakirodalomban a Dénes és mtsai (2015) A magyar labdarúgás története $V$. címü könyvben olvashatunk Várszegi Gáborról abban a fejezetben, amelyben az MTK Budapest bajnoki címét értékelik a szerzők. Ahogyan ebben a részben olvashatjuk, Várszegi Gábor ezekben az időkben az MTK Budapest futballcsapatának elnöke, illetve a Sándor Károly Labdarúgó Akadémia megalapítója és tulajdonosa is volt egyben (Dénes és mtsai, 2015). Várszegi Gábor - Sándor Károly közvetítésével - 1994-ben került az MTK egyesületéhez, éppen az együttes másodosztályba való kiesését követően. Az új vezetővel azonban egyből visszajutott az egyesület az élvonalba, köszönhetően annak, hogy több elismert futballistát is sikerült a klubhoz szerződtetnie (Rábai 2018b).

Kíváncsiak voltunk arra, hogy az agárdi akadémián megkeresett két interjúalanyunk hogyan emlékezik vissza az alapítási időkre, szerintük milyen mértékben van köze a szakirodalom alapján Várszegi Gábornak az első magyarországi labdarúgó akadémia megalakulásához. Az interjúalanyok megerősítették a szakirodalomban találtakat, az első interjúalanyunk így nyilatkozott a kérdés kapcsán: „A Várszegi Úr úgy döntött, hogy több lehetöséget kell a gyermekek felkészitésére adni és ezért alapitotta Agárdon ezt az akadémiát. Meg kellett csinálni az épületet, a pályákat, elöször egy kis kézilabda pálya volt, béreltünk helyet, utána épitett három futballpályát még ott a szomszédban. Úgyhogy ez fokozatosan készült el, a többi akadémia az csak utána alakult".

Interjúalanyunk ezek mellett egy másik fontos tényezőt is említett: „Ehhez ugye pénz kellett, ott kezdödik. Várszegi Úr megépitette a Sándor Károly Labdarúgó Akadémiát, amiröl fogalmam sincs, hogy pontosan mennyibe került. Épitett hozzá pályákat, szóval egy-két év alatt elkészült az infrastruktúra. Elöször a lakhatás volt meg, meg a kisebb pálya, aztán bérelt Agárdon, Velencében pályákat, ahol lehetett edzeni, utána pedig épitett tovább pályákat a meglévökhöz".

$\mathrm{Az}$ agárdi labdarúgó akadémia volt igazgatója hasonlóképpen emlékezett vissza a másik interjúalanyunkhoz, azonban ő bővebben is mesélt a kialakulási körülményekről: „2001-ben alakult a Sándor Károly Akadémia, az MTK akkori tulajdonosa, Várszegi Gábor ismerte fel, hogy az utánpótlásba komoly infrastrukturális és egyéb beruházásokat kell forradalmasitani azért, hogy a legtehetségesebb magyar gyermekek is jó körülmények között tudjanak dolgozni. Egy elég széleskörü tanulmányút elözte meg ennek az akadémiának a létrejöttét, külföldi akadémiákat látogattak meg az MTK akkori szakemberei és azok alapján, 2001-ben indult ez az akadémia elsö, 84'-es korosztálya. Az elsödleges cél az volt, hogy az oktatást, az étkezést és a pihenést is tökéletes összhangba hozzák a futballképzéssel, illetve az ország különbözö részéröl beválogatott tehetségeknek olyan körülményeket biztositsanak, ami segiti a fejlódésüket. 2007-2008-tól a többi klub is felismerte ennek a fontosságát, az MTK akadémiájának mintájára akkortól alakultak az újabb akadémiák Magyarországon (...) azt tudom, hogy jártak Németországban, Franciaországban, Hollandiában, talán még Brazíliában is, ebben nem vagyok biztos, de mintha ott is lettek volna. Ezekbe az országokba mentek el, tehát itt nézték meg az utánpótlásmühelyeket, az akadémiákat" (Rábai 2018b).

A két interjúalany által elmondottak megerōsítették tehát a szakirodalomban olvasottakat, miszerint ténylegesen az MTK akkori tulajdonosának, Várszegi Gábornak az ötletéhez és annak a megvalósításához köthető az első magyar futballakadémia megalapítása. Ugyanezt a történetet olvashatjuk egy szubjektív élményeken alapuló beszámolóban is, amelyben szintén az agárdi akadémia volt igazgatója számolt be a kialakulási körülményekről. Ebben az interjúban is elmondta, hogy a Várszegi Gábor által megálmodott létesítmény és utánpótlás-fej- 
lesztési koncepció alapult meg 2001-ben Agárdon. $\mathrm{Az}$ agárdi akadémia volt szakmai igazgatója a nekünk adott interjújában ezeket azzal egészítette még ki, hogy az akadémia létrejöttét széleskörü tanulmányutak elözték meg, amely során több külföldi utánpótlásbázist is meglátogattak az akkori szakemberek. A tanulmányút befejeztével a legfőbb cél az volt, hogy az ott összegyüjtött tapasztalatokat integrálják a saját módszereikbe, ezzel pedig egy hatékony szakmai fejlesztési koncepciót állítsanak össze, amellyel sikerülhet beindítani az első magyar labdarúgó akadémiát. Az elözetesen felvetett első kutatási kérdésünkre így meg is kaptuk a választ, hiszen az agárdi Sándor Károly Labdarúgó Akadémia megalakulásához érdemben nem volt köze a 90'-es években megjelenő utánpótlás-programoknak és focisuliknak. Várszegi Gábor saját ötletét valósította meg az agárdi akadémia megalapításával, mindezt pedig megalapozták a külföldi tanulmányutak során nyert tapasztalatok, amelyeket később invesztáltak a saját módszereikbe. Ami pedig szintén lényeges információ, hogy mindezt a bázist teljes egészében saját forrásból, állami támogatás nélkül hozta létre Várszegi Gábor (Rábai 2018b). Érdeklődtünk azzal kapcsolatosan is, hogy kellett-e esetleg valami más indító érv ahhoz, hogy ténylegesen elinduljon egy Magyarországon addig még nem létező utánpótlásbázis működése. A Sándor Károly Labdarúgó Akadémia volt igazgatójának a következő volt a válasza a kérdéssel kapcsolatban: „Azért annyit hozzá kell tenni, hogy kellett egy nagyon éles váltás is a szemléletmódban, hiszen addig az MTK elég egyeduralkodó volt a magyar labdarúgásban felnött szinten. Válogatott labdarúgók tömkelege, bajnokságokat, kupákat nyert a felnött csapat, és akkor a Várszegi Úr hozott egy olyan döntést, hogy inkább a fiataloknak adna teret. Tehát igazság szerint az egész futball klubnak a filozófiáját meguáltoztatta és azt mondta ki, hogy a fiatalokat neveljük, a fiatalokat épitsék be a felnött futballba az MTK-n belül, majd - mivel a labdarúgás az egy üzlet - próbálják meg eladni öket akár külföldön, akár tehetósebb magyar csapatoknak".

Ugyanezeket erősítette meg az egyik internetes portálnak nyilatkozva Domonyai László, az MTK Budapest volt ügyvezető igazgatója is. Elmondta a 2010-ben vele készített interjújában, ${ }^{1}$ hogy a szurkolókkal is kötöttek egy sajátos egyezséget, miszerint a legjobbjaikat piacképes korukban igyekeznek értékesíteni, ezzel is fontos bevételi forrásokhoz

1 Forrás: http://m.magyarnarancs.hu/belpol/ futballakademiak_magyarorszagon_-_milliardok_ gyerekcipoben-74839 juttatva az egyesületet: „Ezt a modellt nem biztos, hogy bármely más élvonalbeli csapat megengedheti magának. Nálunk köttetett egy sajátos egyezség a klub és szurkolói között, amit utóbbiak is méltányolni tudnak. Ez részben háttérbe szoritja az eredményességet, de mint a 2007-2008-as példa is mutatja, nem szükségszerüen. Fontos, hogy kellö arányú fluktuáció legyen jelen a felnöttcsapat keretében. A szurkoló nem örül, ha elmegy a Lencse Laci, de ha nem megy el, akkor ma nem lenne helye Tischler Patriknak. A klub akkor tudja finanszirozni az új generációk képzését, ha a legjobbakat piacképes korban értékesiti. Ez sok esetben a játékos érdeke is".

Az agárdi akadémián bevezetett új koncepció sikerességét mi sem bizonyíthatta volna jobban, mint a 2007-2008-as szezonban az agárdi akadémián nevelkedett fiatalokkal megnyert magyar NB I-es bajnoki cím, amely az akadémia alapítása óta eltelt hetedik évben sikerült. Beszédes a már előzőleg említett Dénes és mtsai (2015) által megírt, A magyar labdarúgás története című könyvsorozat V. részének egyik fejezetcíme is a 2007-2008-as évek eseményeiből: „A Sándor Károly Akadémia és Garami József közös bajnoki címe”. A magyar futballtörténelmet górcső alá véve nem számított nagy újdonságnak ez a végeredmény, hiszen abban a szezonban az MTK története során immáron a 23. bajnoki címét ünnepelhette az élvonalban, az viszont annál inkább meglepetés volt, hogy ebben a bizonyos évben az összes versenybe szálló együttes közül a legalacsonyabb átlagéletkorú csapattal nyerték meg a bajnokságot (Dénes és mtsai 2015). Meglepő lehetett ez még annak a függvényében is, hogy az azt megelőző, 2006-2007-es kiírásban az ezüstérmet szerezte meg a Garami József által vezetett fiatal együttes. Ami még szintén fontos statisztikai adat, hogy csupa magyar állampolgárságú játékos alkotta az MTK keretét a bajnoki cím megszerzésének idejében, a csapat magját pedig nagyon tehetséges, ekkor már a magyar felnőtt válogatottban is bemutatkozó fiatalok alkották. Szabados (2008) szerint éppen az MTK fiatalokkal elért átütő sikere kellett ahhoz, hogy a többi elsőosztályú labdarúgó-egyesület is felismerje a fiatalok elötérbe helyezésének lehetőségeit és alapítson saját akadémiát akár Kispesttől Győrig vagy Felcsúttól egészen Szombathelyig (Szabados 2008). A Sándor Károly Labdarúgó Akadémia legelső nagy sikere volt ez a 2007-2008as évben elnyert bajnoki cím, érdemes ugyanis tudni, hogy az MTK-ban abban az idényben pályára lépett 26 játékosból 17-en a Sándor Károly Labdarúgó Akadémián nevelkedtek futballistaként. 
Közülük ebben a méltán sikeres idényben Kanta József, Zsidai László, Rodenbücher István, Hrepka Ádám és Pollák Zoltán egyaránt magyar felnőtt válogatottnak mondhatta magát (Dénes és mtsai 2015). Mindemellett az 1989-es agárdi akadémián nevelkedő korosztályra építkező utánpótlás-válogatott a 2006-os évben ötödik lett az U-17-es Európa-bajnokságon, de a 2008-as U-18-as EB-n, illetve az egy évvel későbbi U-20-as világbajnokságon már egyaránt bronzérmet szereztek a fiatal labdarúgók. Egyébként az MTK együttese azóta sem tudta véghezvinni ezt a bravúros szereplést, sőt, a három évvel későbbi szezonban (2010-2011) a 30 bajnoki mérkőzés alatt szerzett 30 pontjával az utolsó előtti helyen végezve kiesett az NB I-ből (Dénes és mtsai 2015). Ahogyan az akkori publicisztikákból is kiderül, a Várszegi-féle futballreform gyakorlatilag ezzel a kieséssel összeomlott, hiszen a történtek után nem sokkal az MTK tulajdonosa és a Sándor Károly Labdarúgó Akadémia egykori alapítója kiszállt az együttes működtetéséből. Mindez azt jelentette, hogy hiába volt a három évvel azelőtti bajnoki cím, a Várszegi-féle koncepció ezzel a kieséssel mégis megbukni látszott. Egy év másodosztályú szezon elteltével azonban egyből visszajutottak az NB I-be, onnantól fogva pedig évekig stabil tagjai voltak az elsőosztályú mezőnynek, jelenleg viszont újra a második vonalban szerepelnek. Ugyanezeket a tényeket az akadémia volt igazgatója is megerősítette nekünk: „Nagyon fontos, hogy nálunk nem csak az történt meg, hogy össze tudtuk szedni az ország legtehetségesebb gyermekeit és jó feltételeket adtunk nekik, hanem egy egész klubnak a filozófiája változott meg. Rendkivül fiatal volt a csapatunk, mindig legalább 75 \%-a a keretnek saját nevelésü volt. Ebbe belefért az, hogy bajnokok lettünk, belefért az, hogy volt egy év, amikor kiestünk. Nem engedték el a csapatot, nem engedték szétszéledni, együtt maradtunk, nem rúgták ki az edzöt, visszajutottunk és egyböl negyedikek lettünk. Most az, hogy miért esett ki a csapat abba ne menjünk bele, azok elég zivataros évek voltak, mint késöbb kiderült, sajnos szerepet játszott a bundabotrány is. Úgyhogy erröl most ne beszéljünk" (Rábai 2018b).

Gősi és Sallói (2017) szerint a szövetség fiatalszabályának eredményeképpen noha több fiatal játékos szerepel az NB I-es és NB II-es futballcsapatokban, az akadémiák jelenleg a tömeget mégis a másod- és harmadosztályú együttesek számára képzik. Eredményeik szerint az edzők fiatalokat szerepeltető stratégiájának hátterében jelenleg inkább gazdasági, mintsem sportszakmai indokok állnak (Gősi - Sallói 2017). Természetesen a szö- vetségben is felismerték a kialakult helyzetet, 2018 márciusában pedig reagáltak is: új fiatalkoncepció kerül bevezetésre 2018 nyarától, amely fókuszában marad a fiatalok minél gyakoribb szerepeltetési lehetősége, ugyanakkor a központi eleme az újonnan kialakított produktivitási rendszer lesz. Ennek a lényege, hogy az MLSZ egy objektivitáson alapuló rendszerben kizárólag a teljesítmény és a pályán töltött idő alapján fogja ezután honorálni a fiatal játékosokat preferáló együtteseket. A TAO-rendszer - mint alaptámogatási forma - megmarad továbbra is, azonban a produktivitási támogatásban ezentúl csak azok az együttesek részesülhetnek, amelyek érdemileg részt vesznek profi és/vagy utánpótlás, vagy pedig a felnőtt válogatottban szerepléshez jutó játékosok nevelésében. Magát a támogatás mértékét pontszámítási rendszerben kívánja meghatározni az MLSZ, tehát minél több és minél magasabb szintekre nevel egy adott klub egy-egy játékost, annál nagyobb támogatást kaphatnak a szövetségtől. Egyelőre még megválaszolatlan kérdés, hogy a 2018 nyarán bevezetésre kerülő új koncepció vajon mennyire hat ösztönzőleg az élvonalbeli együttesek számára annak érdekében, hogy minél több fiatalt helyezzenek előtérbe a hatékony fejlődésük érdekében (Rábai 2018b).

A kutatásunk e részének eredményeképpen kiderült tehát, hogy a Sándor Károly Labdarúgó Akadémia megalapítása Várszegi Gábor nevéhez füződik, aki saját elgondolásból és forrásból alapította meg az agárdi akadémiát annak érdekében, hogy minél több fiatalt tudjanak professzionális szinteken fejleszteni a saját módszereik és bázisuk segítségével. Az akadémia tényleges létrejöttét széleskörű tanulmányutak előzték meg, amelyek során az akadémián dolgozó szakmabeliek információkat és adatokat gyűjtöttek az egyes külföldi akadémiák mủködéséről, majd ezeket az ismereteket integrálták saját gyakorlatukba.

Az alfejezet további részében - az előbb ismertetett kérdések mentén - a Debreceni Labdarúgó Akadémia kialakulási körülményeit tártuk fel és hasonlítottuk össze az előbb bemutatott agárdi akadémia megalakulásával. Érzéseink szerint a Debreceni Labdarúgó Akadémia létrejötte merőben más indíttatások alapján valósulhatott meg, mint amit Agárdon láthattunk. Ezt az állításunkat arra alapozzuk, hogy egy sikeresnek számító, az akadémia-alapítás második hullámához tartozó vidéki akadémia esetében nem feltétlen a magánszemélyek elsődleges támogatása, hanem inkább az alulról jövő helyi, közösségi igények, erők szerepvállalása lehetett a 
kulcs, amelyet a már korábban említett LearnInnov (Kozma és mtsai) kutatás keretein belül tudtunk megvizsgálni.

A tényleges feltárás érdekében a Debreceni Labdarúgó Akadémia megalakulása kapcsán kérdeztük az akadémia szakmai igazgatóját, aki a következőket válaszolta a kérdésünkre: „Az MTK-nál alakult meg elöször, ez akkor a világban elfogadott dolog volt. Miután ez az akadémia megalakult az MTK-nál, onnantól kezdve egyre több akadémia jött létre hazánkban. Azt gondoltuk, hogy ebbe a kialakuló rendszerbe Debrecennek is bele kell kapcsolódnia és így alakult meg tulajdonképpen nálunk az akadémia”. Hozzátette, hogy az is fontos volt továbbá, hogy javítsanak a gyermekek optimális fejlesztéséhez szükséges feltételeken: „Jobb körülményeket tudjunk biztositani a gyerekeknek, azt gondoltuk, hogyha egy helyen van az iskola, az étkezésük, a pihenésük, illetve jobban adottak a feltételek az edzésekhez, akkor mindenképpen hatékonyabb a velük való foglalkozás. Nem kell a gyereknek fölöslegesen több órát utazással eltölteniük, ami szintén fó motiváció volt". Az interjúalanyunktól megkérdeztük még a kialakulási körülmények átfogóbb feltárása érdekében, hogy az akadémia megalakulása elött milyen gyakorlatokat alkalmaztak Debrecenben, mi volt az akadémia előtt a debreceni labdarúgó-utánpótlásképzésben. Interjúalanyunk ezekről az időkről a következőket mondta az interjújában: „Akkor is volt bázisiskolánk, a Hunyadi János Általános Iskola, illetve az Irinyi János Gimnáziumban. Ugyanúgy megvoltak a labdarúgó és a kézilabda-osztályok, fele kézilabdás lány, fele labdarúgó fiu volt. Nálunk akkor is müködött a rendszer, ez a Debreceni Sportiskola volt akkor, azt követöen lett a DVSC Utánpótlásnevelö Kft., ugyanúgy megvoltak a lehetöségek, nagyon jól és szervezett körülmények között müködött". Igyekeztünk mélyebb összefüggéseket is feltárni a Debreceni Labdarúgó Akadémia története kapcsán, ezért megkérdeztük az akadémia szakmai igazgatójától, hogy mi ihlette azt az elhatározást, hogy Debrecenben ténylegesen is akadémia létesüljön a 2010-es évben. Vajon melyek voltak azok a konkrét előzmények, amelyek az akadémia megalakulásához vezethettek. Interjúalanyunk elmondta a válaszában, hogy Debrecenre mindig is jellemző volt a törekvő attitűd és a fejlődőképesség, emellett rendkívül fontos tényező volt a Debreceni VSC akkori remek szereplése mind a hazai, mind pedig a nemzetközi színtereken tekintve: „Debrecen azért mindig egy fejlödo", törekvo" város volt, az itt élo" emberek mindig akartak fejlödni, tanulni, továbblépni. Amikor alakultak az akadémiák hazánkban, azokban az idökben a Debreceni VSC jól szerepelt a hazai porondon, hiszen sorra nyerte a bajnokságokat, emellett a nemzetközi kupákban több izben is megmérethették magukat. Ekkor úgy döntöttek a vezetök, hogy lépni kell, hogy még egy kategóriával magasabb szinten tudják képezni a gyerekeket, tudjanak fejlödni és nálunk is legyen akadémia". Ezzel kapcsolatban az akadémia szakmai vezetője hozzátette, hogy a nemzetközi kupákban való szereplés lehetőséget biztosított arra is, hogy a külföldön zajló utánpótlás-nevelésbe betekintést nyerjenek, ezáltal fontos tapasztalatokat gyüjtsenek és azokat integrálják a saját képzési rendszerükbe. Interjúalanyunk szerint a Debreceni Labdarúgó Akadémia megalakulását a városra jellemző állandó fejlődőképesség és a felnőtt labdarúgócsapat rendkívül sikeres szereplése ihlette meg mind a hazai, mind pedig a nemzetközi színtereket figyelembe véve. De vajon önmagában elegendő lehet-e egy akadémia létrehozásának tekintetében az, hogy egy vidéki nagyváros felnőtt csapata eredményesen szerepel a hazai és a nemzetközi porondokon? A Debreceni Labdarúgó Akadémia szakmai igazgatója tovább folytatta az imént elindított gondolatmenetét: „Ebbe nagy összefogás volt helyi szinten, az akadémiának ugyanis három tulajdonosa van, a DVSC Futballszervezö Zrt., a Debrecen Megyei Jogú Város Önkormányzata és a Debreceni Egyetem. Tulajdonképpen ez az összefogás predesztinálta az akadémia valódi létrejöttét".

Láthatjuk tehát, hogy a Debreceni Labdarúgó Akadémia létrehozásának lehetőségét az akkori felnőttcsapat sikeres szereplése ihlette meg, de ennek a megvalósításához elévülhetetlen szerepet vállalt a helyi erőket képviselő tulajdonosi kör hathatós összefogása. Mindehhez azonban szükség volt a felülről jövő erők anyagi forrásbiztosítására is, amellyel ténylegesen megalakulhatott az akadémia Debrecenben: „Nem szabad elfelejteni a kormány támogatását a TAO-t illetöen, nagyon jelentös kormányzati támogatást kaptunk, hogy létrejöjjön ez a központ. A helyi erök mindent elkövettek, de kellett hozzá a kormány támogatása a TAO-n keresztül...”. A szakmai vezető interjújában konkrét közreműködő neveket, ,helyi hősöket” ugyan nem emelt ki, de azt hozzátette, hogy: „Mindenki tevékeny volt, aki ebben részt vett". Kíváncsiak voltunk még ezek mellett arra is, hogy mi volt a lakosság reakciója azok után, hogy 2010-ben Debrecen-Pallagon labdarúgó akadémia létesült. Az interjúalanyunk szerint mindenki pozitívan és reményekkel telve fogadta az akadémia megalakulásának hírét egyaránt a sportszakma és a lakosság körében is: „Mindenki nagyon 
boldog volt, hogy Debrecenben is ez megadatott, hogy a gyerekeink ilyen körülmények között készülhetnek...". Megkérdeztük azt is az interjúalanyunktól, hogy mit gondol a sikeres müködéshez elengedhetetlen feltételek (iskola, kollégium, akadémia infrastrukturális háttere, stb.) meglétéről Debrecenben és Pallagon. A válaszában elégedetten nyilatkozott a szakember a Pallagon található infrastruktúráról, egyedül a kollégium tekintetében említett hiányosságokat, ahol egyébként körülbelül 70 vidéki debreceni akadémista van elszállásolva jelenleg: „A létesitmény az kiváló, hiszen nyolc nagyméretü füvespálya és hét egyéb méretü müfüvespálya áll rendelkezésre öltözökkel, konditeremmel, elöadóteremmel. A bázisiskolánk a Balásházy János Gyakorló Középiskola. A kollégiumot kell fejleszteni, mert az még sajnos nem az igazi, de ezt leszámitva azt gondolom, hogy kiváló feltételeink és lehetöségeink vannak. Kaptunk igéretet a kollégium felújitására, amelyet el is kezdtünk, tehát úgy gondolom, hogy az is hamarosan közel lesz az edzöközpont minöségéhez".

Amennyiben a Debreceni Labdarúgó Akadémia megalakulási körülményeiről való ismereteinket szeretnénk összegezni, akkor három fontos momentumot érdemes kiemelni és megemlíteni ezzel kapcsolatban: a Debreceni Labdarúgó Akadémia megalakulásának első lépéseként értelmezhető a felnőtt csapat akkori kiemelten sikeres időszaka a hazai, illetve a nemzetközi porondokon, amellyel kialakult egyfajta igény a további fejlesztésre, fejlödésre. Ezt követte a helyi közösségek, erők összefogása, akik segítségével elindultak a megvalósításig vezető úton. Interjúalanyunk szerint ehhez mindhárom fenntartó lelkes, szövetséges munkájára volt szükséges, akik együttesen kezdték el megvalósítani az előzetesen elképzelt koncepciót és kialakítani az ehhez szükséges infrastrukturális hátteret. A felülről jövő erőt, az anyagi forrást a kormányzat támogatása jelentette, akik a TAO-rendszeren keresztül tudtak támogatást nyújtani a magas szintű infrastruktúra kialakításának érdekében. A Debreceni Labdarúgó Akadémia 2010-től működik Debrecen-Pallagon és nyújt közel 220 gyermek számára magas szintü fejlődési lehetőséget Hajdú-Bihar megyében. Az akadémia mindemellett kiemelt RUK-központként működik, így tagja a kiemelt 12 akadémiának hazánkban.

A kutatás összegzéseként elmondható, hogy a leginkább 90'-es évekre tehető, a labdarúgó utánpótlás-fejlesztést fókuszba állító programoknak és focisuliknak nem volt érdemi köze a 2001-ben megalapított Sándor Károly Labdarúgó Akadémi- ához. Ezzel párhuzamban markáns különbségeket véltünk felfedezni az agárdi Sándor Károly Labdarúgó Akadémia és a Debreceni Labdarúgó Akadémia megalakulási körülményei között. A Sándor Akadémia esetében egy magánszemély által kezdeményezett, széleskörü külföldi tanulmányutakra megalapozott koncepció önerőből történő megvalósulását láthattuk, míg a Debreceni Akadémia tekintetében részint a felnőtt csapat akkori eredményes szereplése, részint pedig a helyi, közösségi erők összefogása és ténykedése indukálta az akadémia akkori megalakulását.

Jövőbeli terveink között szerepel, hogy a már említett LearnInnov kutatás (Kozma és mtsai) keretein belül további akadémiákat vegyünk vizsgálat alá ugyanezen szempontok alapján, a nagyobb mintha segítségével pedig könnyebben tipizálhatóvá válhatnak az intézmények a kialakulási körülményeik aspektusában.

\section{4. Összegzés}

Jelen tanulmányunkban arra vállalkoztunk, hogy az agárdi Sándor Károly Labdarúgó Akadémia és a Debreceni Labdarúgó Akadémia kialakulási történetét vizsgáljuk meg és hasonlítsuk össze egymással a szakirodalom és a témában felvett féligstrukturált interjúbeszélgetések segítségével.

A kutatásunk eredményeképpen markáns különbségek mutatkoztak a két általunk vizsgált labdarúgó akadémia kialakulási körülményei között. Az agárdi Akadémia megalapításának esetében egy magánszemély általi kezdeményezésről beszélhetünk, aki saját elgondolásból és forrásból alapította annak érdekében, hogy minél több fiatal labdarúgót tudjanak professzionális szinteken fejleszteni az akadémia berkein belül. A kutatás során kiderült továbbá, hogy hazánk első labdarúgó akadémiájának létrejötte nincs szoros összefüggésben a 90'-es években megjelenő, legföképpen a hazai labdarúgó utánpótlás-nevelés magas szintekre való emelésében szerepet játszó programokkal és utánpótlásbázisokkal. A Debreceni Akadémia az agárdihoz képest később, közel 9 év múlva jött létre. Interjúalanyunk beszámolója alapján itt nem egy magánkezdeményezésről, hanem ezzel ellentétben a helyi, közösségi erők összefogásának és szerepvállalásának eredményeképpen jött létre az akadémia. Mindehhez azonban kellett az a lényegi momentum is, hogy a Debreceni VSC akkori felnőtt együttese kiemelkedően szerepelt mind a hazai, mind pedig a nem- 
zetközi színtereken, amely egyfajta igényt predesztinált az utánpótlás-fejlesztés magasabb szintekre emelése érdekében. Ehhez kellett a helyi, közösségi erők erős összefogása, akik helyi szinteken tettek meg mindent annak érdekében, hogy Debrecenben akadémia létesüljön. Mindehhez jött - mint egyfajta felülről jövő erőként - a kormányzat jelentős anyagi támogatása, amely segítségével ténylegesen is megalakult a Debreceni Labdarúgó Akadémia Debrecen-Pallagon 2010-ben.

A kutatás folytatásaként érdekes kérdésként merül fel, hogy további akadémiák bevonásával milyen azonosságokat vagy különbségeket tudunk majd felfedezni további labdarúgó akadémiák kialakulási körülményeivel kapcsolatosan annak a tükrében, hogy az előzetes kutatásaink alapján a labdarúgó akadémiák eltérő fenntartói, mủködésbeli sajátosságokkal rendelkeznek (Fenyő - Rábai 2016). A fö jövőbeli terveink közé tartozik tehát a minta bővítése és további akadémiák vizsgálata elsősorban a mostani kutatásban alkalmazott kérdések mentén.

\section{Felhasznált szakirodalom}

Csáki István - Bognár József - Trzaskoma-Bicsérdy Gabriella - Zalai Dávid - Mór Ottó - Révész László - Géczi Gábor 2013 A sportágválasztás, a tehetséggondozás és az edző sportoló kapcsolat vizsgálata elit utánpótláskorú labdarúgók körében. Magyar Sporttudományi Szemle, 14. 55:9-16.

Dénes Tamás - Sándor Mihály - B. Bába Éva 2015 A magyar labdarúgás története (18972015) I-V. kötet. In Bács Zoltán szerk. A futball elhuizódó rendszerváltozása (1986-2015). Campus Kiadó, Debrecen, 475-478.

Fenyő Imre - Rábai Dávid 2016 A sporttehetséggondozás jogszabályi környezete - a sportakadémiák Magyarországon. In Kovács K. szerk. Ertékteremtö testnevelés: Tanulmányok a testnevelés és a sportolás szerepéröl a Kárpát-medencei fiatalok életében. CHERD-H, Debreceni Egyetemi Kiadó, Debrecen, 65-88.

Gősi Zsuzsanna - Sallói István 2017 Rögös út a sportkarrier: A fiatal magyar labdarúgók karrieresélyei. Magyar Sporttudományi Szemle, 18. 72:11-19. https://doi. org/10.1556/0016.2017.72.2.1
Rábai Dávid 2016 Élet a labdarúgó akadémiákon - egy pilot kutatás eredményei. In Farkas E. - Nagy J. - Polyák E. - Szabó É. szerk. A mi tendenciáink... Szakkollégiumi tanulmányok 4. Debreceni Egyetem Hatvani István Szakkollégium, Debrecen, 70-87.

Rábai Dávid 2018a A magyar sportpolitika legföbb jellemzői, intézkedései 1945-től kezdődően a rendszerváltásig és napjainkig, különös tekintettel a labdarúgás sportágára. Különleges Bánásmód, 4. (1):7-17.

Rábai Dávid 2018b A magyar labdarúgó akadémiai rendszer kialakulásának története és a Sándor Károly Labdarúgó Akadémia jelen gyakorlatának bemutatása. Magyar Sporttudományi Szemle, 19. 74:52-58.

Szabados Gábor 2008 A labdarúgóklubok stratégiái. In Krausz T. - Mitrovics M. szerk. A játék hatalma: Futball-pénz-politika. Kelet-európai tanulmányok II. L'Harmattan Kiadó, ELTE BTK Kelet-Európa Története Tanszék, Budapest, 58-76.

Szegedi Péter 2003 Az utánpótlás-nevelés a magyar labdarúgás struktúrájában. Századvég, Budapest

Vincze Géza 2008 Az 1989-1990-es politikai rendszerváltás hatása a labdarúgó utánpótlás nevelésre. Disszertáció, Semmelweis Egyetem Sporttudományok Doktori Iskola, Budapest.

\section{Interjúbeszélgetések}

\section{Internetes forrás}

http://m.magyarnarancs.hu/belpol/ futballakademiak_magyarorszagon_-milliardok_gyerekcipoben-74839 